\title{
Common Sun Skink Eutropis multifasciata (Kuhl 1820) sold for Traditional Medicine in Indonesia and potential conservation implications
}

\author{
Jordi Janssen ${ }^{1^{*}}$ and Lalita Gomez ${ }^{2}$
}

\begin{abstract}
Reptiles are one of the most frequently encountered animal species in the trade for traditional medicine. The use of reptiles for medicinal purposes has been documented throughout the world, impacting dozens of species. Despite the broad occurrence of reptiles in medicinal trade, there is a general lack of information concerning the scale or impact of this trade and the species involved. Here we report the sale of Common Sun Skinks Eutropis multifasciata on the island of Java in Indonesia. We surveyed 13 wildlife markets and three reptile pet stores in eight cities across Java, documenting 110 Common Sun Skinks in trade in six markets in five cities. This skink is sold for traditional medicinal purposes with several vendors stating its use to treat skin problems like "itchiness". This particular use has not been well documented in Indonesia. Further, the Common Sun Skinks were primarily sold by vendors selling Tokay Geckos for a similar purpose. This is of potential conservation concern as Tokay Geckos are harvested en masse for medicinal purposes which has resulted in significant population declines, and this could lead to potential over-exploitation of the Common Sun Skink in response to this decline.
\end{abstract}

Keywords: Ethnozoology; Wildlife Trade; Tokay Gecko; Zootherapy

\footnotetext{
1, 2 Monitor Conservation Research Society, Big Lake Ranch BC, PO Box 200, VOL 1G0, Canada

* Corresponding author. $\square$ E-mail address: JJ (jordi.janssen@mcrsociety.org)
}

\section{INTRODUCTION}

The use of natural resources, wild plant and animal species, for medicinal purposes is widespread and has been in practice for thousands of years (Alves et al. 2008; Feng et al. 2009). Approximately $80 \%$ of the world's population still rely on the use of natural resources for traditional medicine (Costa-Neto, 2005). This is particularly evident in developing countries, as it is often more affordable in comparison to modern medicine, and in remote areas, it can be the only form of medicine available (Sofowora, 1996, Alves et al. 2007, Alves and Rosa, 2010). Traditional medicine is strongly influenced by social, economic and cultural practices, which has led to a higher preference for traditional medicine over modern medicine (Nazarea et al. 1998; Ngokwey, 1995).

Of all animal species used in traditional medicine, reptiles are one of the most frequently encountered (Alves et al. 2008) 
and their use has been recorded throughout the world (Alves and Rosa 2006; Mahawar and Jaroli 2006; Nijman and Bergin, 2017; Enríque Vazquez et al. 2006; Williams et al. 2016; Zhou and Jiang 2004). Alves et al. (2013) reported that at least 284 species of reptiles are used in traditional medicine around the world, a large percentage (64\%) of which are classified as threatened. They also note that this is likely an under representation of the true scale of reptiles used in traditional medicine as so few are documented.

Reptiles have been widely used to treat a large variety of ailments like coughs (Read, 1934), asthma (Chuang et al., 1999; Sheu, 1977), diabetes (Read, 1934), cancer (Chen and Huang, 2001), hyperglemia (You and Wang, 2000), skin problems, bruises, sprains, arthrosis, rheumatism (Alves et al. 2009) and many others. Where only certain parts are used for some species (e.g. fat or skin) for other species multiple parts are used, resulting in the use of one species for up to a couple dozen different ailments (Alves et al. 2009). The use of certain species seems to be reflected in the way that species is perceived in the local community (Bauer, 2009).

While the use of reptiles for medicinal purposes is relatively well documented, information of its scale or magnitude of the harvesting of species for this purpose is lacking (Alves and Pereira-Filho 2007). That said, the potential conservation implications of the traditional medicine trade on reptiles has been gaining attention in recent years (Alves et al. 2009; Chen et al. 2009; Gong et al., 2009; Nijman et al., 2012; Nijman and Bergin. 2017; Whiting et al. 2013). For lesser known reptiles a negative impact by trade is more difficult to detect (Byard, 2016; Nijman et al., 2012; Rowley et al., 2016), as basic information on conservation status is often lacking (Meiri et al. 2017). It is therefore imperative that the scale of trade for traditional medicine and the impact on wild populations is monitored and included in conservation status assessments. Here we document the sale of Common Sun Skinks Eutropis multifasciata for medicinal purposes on the island of Java, Indonesia. The Common Sun Skink is a widespread species that can be found from India, China and Myanmar throughout Southeast Asia (Shea et al. 2018).

\section{MATERIAL AND METHODS}

Wildlife markets/stores known for selling animals as pets were surveyed across Java between 4 October and 14 October 2018 to document the open availability of reptile species in trade. It encompassed 13 markets and three reptile pet stores in eight cities (Figure 1). During the survey, large numbers of Common Sun Skinks were observed at some markets and a local guide and translator explained that these were used for medicinal purposes. Vendors were opportunistically asked questions about the use, preparation and price of this species in Indonesian with the assistance of a local guide and translator. The quantity of individuals observed in trade were recorded accurately or in some cases estimated (i.e. when not all animals were visible or when large numbers were clumped together in a single enclosure). Prices were converted using the average exchange rate during the study period as found on https://www.oanda.com/fx-for-

business/historical-rates, this resulted in 1 USD= 15.186,20 IDR.

It should be noted here that the use of this species in the traditional medicine trade was not the primary goal of the survey 


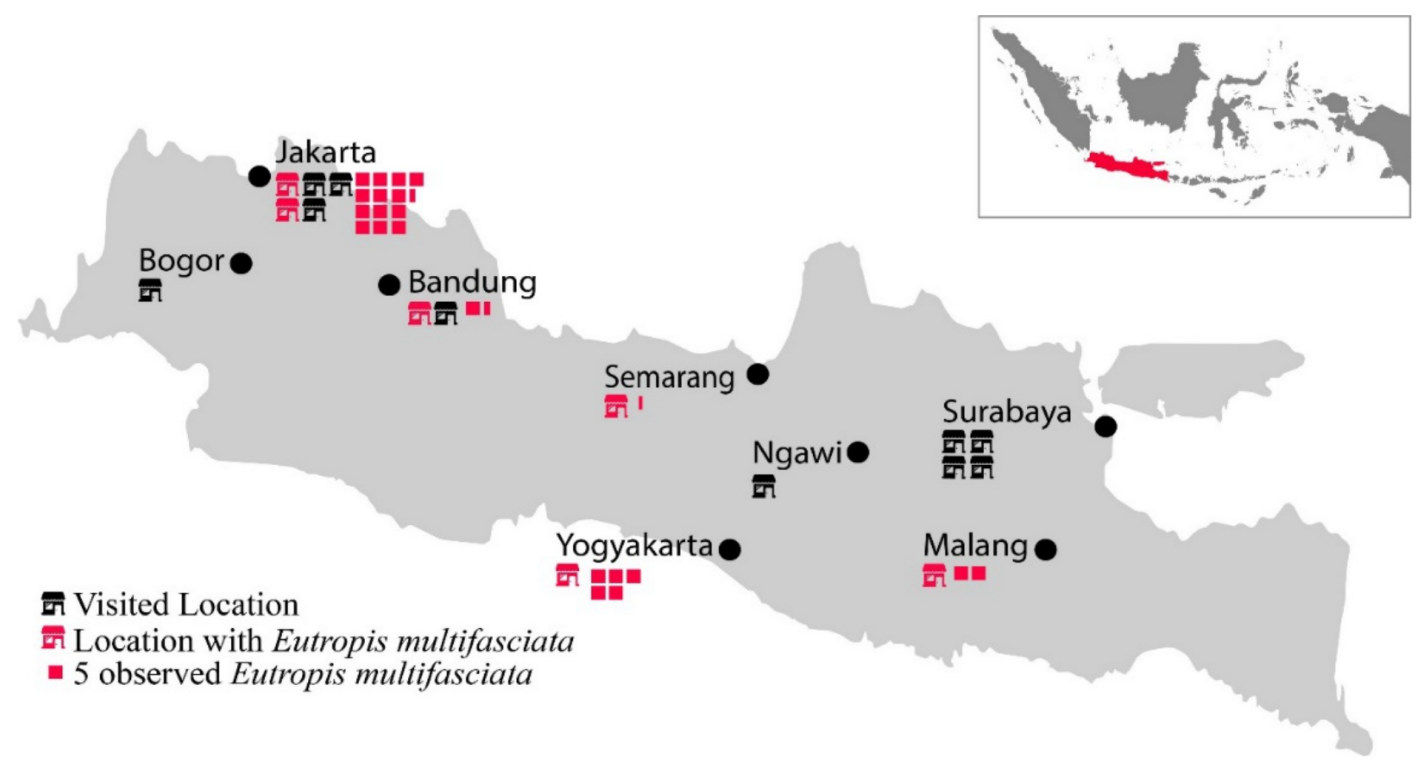

Figure 1. Overview of the visited locations (each symbol = one visited location) and the number of markets where Eutropis multifasciata was observed (coloured symbol). The number of Eutropis multifasciata is displayed with cubes, for which each cube stands for 5 observed animals.

(Janssen et al. in prep). However, there is very little published information of this species usage for medicine. The purpose of this paper was therefore to document this observation so that the information is available and can be used to understand and assess the full spectrum of potential threats facing this species.

\section{RESULTS}

An estimated 110 Common Sun Skinks were observed in six markets in five cities across Java (Figure 1 and 2). Jakarta had the highest quantities of the species observed in trade, with a total of 67 animals encountered at four stalls in two markets (Pasar Hewan Jatinegara and Gunung Sahari). This was followed by Yogyakarta with 25 Common Sun Skinks (Figure 2). On average, this was estimated to amount to 22 animals per market (range 1-67), and 11.95 animals per stall (range 1-25).

Two price estimates were obtained for the Common Sun Skink. A vendor in Yogyakarta at Pasar Satwa dan Tanaman Hias quoted IDR 15.000 (USD 0.99) per animal, while a vendor in Jakarta (Pasar Hewan Jatinegara) quoted IDR 35.000 (USD 2.30) per animal. Six out of the eight vendors found selling the Common Sun Skink, also sold Tokay Geckos Gekko gecko. The price of Tokay Geckos was size dependent with IDR 10.000 (USD 0.66) for a small animal, IDR 30.000 (USD 1.98) for an average size gecko and IDR 50.000 (USD 3.29) for a large gecko. Both species are sold primarily for use in traditional medicine. Our local guide and translator stated that these skinks are used to treat skin problems like "itchiness". This was later confirmed by two more vendors selling the skinks. One vendor stated that the Common Sun Skink had the same use as the Tokay Gecko which is also used to 


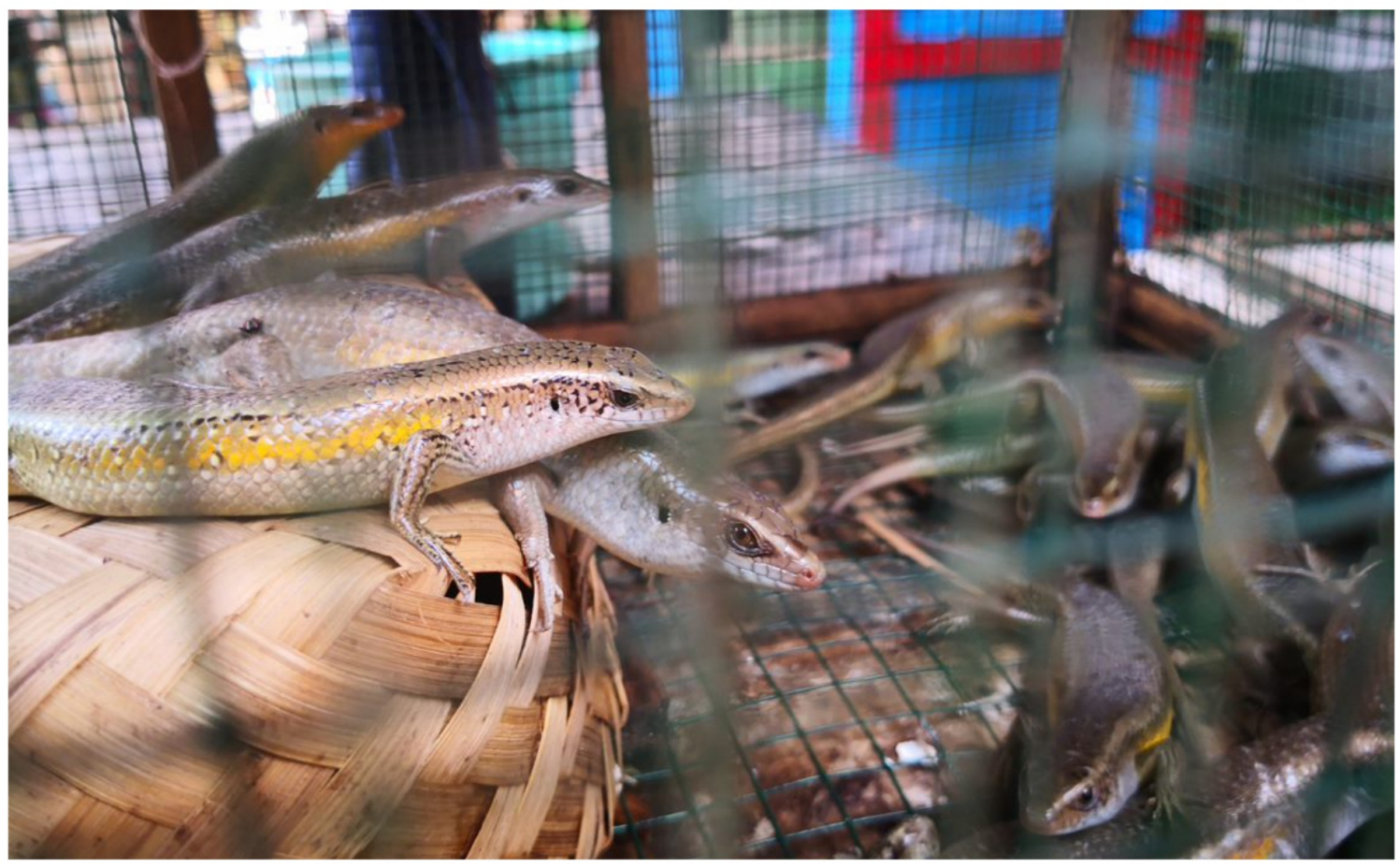

Figure 2. Common Sun Skinks Eutropis multifasciata for sale at Pasar Satwa dan Tanaman Hias in Yogyakarta. Species identification confirmed by M.Auliya. () Monitor Conservation Research Society.

treat skin problems. The vendor also stated that the Tokay Gecko was better than Common Sun Skinks in this respect but could not explain why. Another vendor stated that the Common Sun Skinks are used by eating them whole or grilled on the barbeque.

\section{DISCUSSION}

Previous studies have revealed the trade of the Common Sun Skink as pets in Indonesia (Yuwonoi, 1998). However, the sale of this species for medicinal purposes is only sparsely documented. There has only been one other case recently describing a similar use of Common Sun Skinks specifically to treat skin problems in the Kokrajhar District of Assam, India (Hazarika and Sharma, 2017). They reported that $60 \%$ of all people interviewed were aware of its use and it generally encompassed the entire animal, or its parts or products like blood, bones or dried skin (Hazarika and Sharma, 2017). However, Nijman and Nekaris (2014) reported the sale of "Skink oil" on the Indonesian island of Bali, yet, do not report what species it is. Arisnagara (2009) also reports the findings of a skink species (Eutropis spp.) sold at one stand, for medicinal purposes, in Jakarta. The latter could well be the Common Sun Skink and would confirm our observations. In addition, Arisnagara (2009) mentions that the skinks are consumed in the form of sate (similar to our observation) and are used for similar ailments. Of interest is also Arisnagara (2009)'s observation that the skinks are harvested locally and not farmed, suggesting the medicinal trade in this species is mostly local, in contrast to their other use, the international pet trade.

The sale of Common Sun Skinks for traditional medicine across Java is a 
potential conservation concern, as it appears to be an alternative for the medicinal use of Tokay Gecko, but there seems to be little documentation and no regulation of its use for this purpose. Large discrepancies have been observed in the trade of Tokay Geckos in Indonesia, with several studies showing that this species is laundered en masse for the traditional medicine industry, both locally and internationally, and is now considered the biggest threat to the species (Auliya and Shepherd, 2007; Nijman et al., 2012; Nijman and Shepherd 2015). The harvest and export of Tokay Geckos is likely unsustainable with individuals involved in the trade having noticed a significant local decline of the species (Nijman et al. 2012). For this reason, the Tokay Gecko was recently listed on Convention on International Trade in Endangered Species of Wild Flora and Fauna (CITES) Appendix II, allowing for trade to only occur under a permit system.

In this study, only 13 wildlife pet markets were visited of which six offered Common Sun Skinks for sale. However, wildlife markets for the purpose of pets are common throughout Indonesia and over 70 such markets are found in Java alone (ProFauna, 2009). In addition, based on discussions with vendors, it is likely that this species is also found in markets for human consumption and medicinal purposes. With "skink oil" being observed outside Java as well (Nijman and Nekaris, 2014), this species and its products might potentially be for sale at hundreds of markets throughout Indonesia.

Declines reported for Tokay Geckos could shift focus of trade to the Common Sun Skink (i.e. it was observed for sale at the same stalls offering Tokay Geckos and for similar purposes) and there is a concern similar over-exploitation of the species could potentially arise if left unchecked. Such concerns have previously been voiced for the Caucasian Agama Paralaudakia causasia which was observed for sale in dried form as "gecko" in a Chinese Medicine Market in Afghanistan (Wagner and Dittmann, 2014); for freshwater tortoise and turtles in Asia harvested for food and medicine (Alves et al 2013); for Saiga Antelope harvested for their horns and meat (Milner-Gulland et al. 2001); and for a myriad other species where populations declines have been associated with traditional medicine use particularly where this has involved commercialisation and international trade for this purpose (Alves and Rosa, 2013; Lee et al., 2015; Nijman and Shepherd, 2015; Stoner and Krishnasamy, 2016; Njiman and Bergin, 2017).

The Common Sun Skink is currently not protected by law in Indonesia but is included in harvest and export quotas for pets only. Yet, no quota has been set for the harvest of this species for medicinal purposes. In 2010, Indonesian authorities authorized the harvest and export of 9000 Common Sun Skinks for the pet trade (KSDAE, 2010). Since then, harvest quotas were reduced to 4200 (3780 for export) in 2016 (KSDAE, 2016) and 2000 (1800 for export) in 2018 (KSDAE, 2016; KSDAE, 2018). Harvest quotas in 2016 and 2018 were allocated to the provinces South Sumatra, West- and Central-Java, Papua and West Papua (KSDAE, 2016; KSDAE, 2018).

\section{CONCLUSIONS}

The Common Sun Skink is a widespread and relatively common species. Based on this study alone, it is impossible to determine whether the use of this species in traditional medicine is a significant threat or otherwise. Nevertheless, it is essential that the different uses of the species are documented. This 
species is currently classified as Least Concern on the IUCN Red List, an assessment which was published in 2018 . This assessment reports that the species is exported for the pet trade (Yuwono, 1998), but specifically states that it is not used in traditional medicine (Shea et al. 2018). This in contrast to the results presented in this study, as well as in Hazarika and Sharma (2017), Arisnagara (2009) and Nijman and Nekaris (2014). These studies also suggest that the medicinal use of Common Sun Skinks has been occurring for considerable time and could be more widespread than expected. In addition, this species is also used as bait for fish as well as food for fish and birds (N. Rusli pers. comm.). If looked at in isolation, the trade for traditional medicine might not be the most significant threat for this species but when combined with other factors i.e. habitat loss, harvesting for the pet trade, bait and human consumption, a more significant threat assessment may arise. Declining population of this species due to over-collection have been documented in e.g. India (Hazrika and Sharma, 2017). It is therefore imperative that all potential threats to a species are documented as accurate threat assessments can only be made based on the cumulative sum of all threats a species is facing.

\section{ACKNOWLEDGEMENTS}

The authors would like to thank a donor who wishes to remain anonymous for supporting our work on live reptile trade in Southeast Asia. Furthermore C.R. Shepherd is thanked for useful and constructive feedback on previous versions of this manuscript. V. Nijman is thanked for help translating documentation about medicinal trade of skinks in Indonesia. Two anonymous reviewers are thanked for constructive feedback on a previous version of this manuscript.

\section{REFERENCES}

Arisnagara, F. (2009). Pemanfaatan Reptil sebagai Obat dan Makanan di Daerah Khusus lbukota (DKI) Jakarta.[Skripsi]. Institut Pertanian Bogor. Bandung, Indonesia

Alves RRN, Rosa IL (2006) From cnidarians to mammals: The use of animals as remedies in fishing communities in NE Brazil. Journal of ethnopharmacology 107:259-276.

Alves RRN, Neto NAL, Santana GG, Vieira WL, Almeida WO (2009) Reptiles used for medicinal and magic religious purposes in Brazil. Applied Herpetology 6:257-274.

Alves RRN, Rosa IL, Santana GG (2007) The role of animal-derived remedies as complementary medicine in Brazil. AIBS Bulletin, 57:949-955.

Alves RRN, Pereira-Filho GA (2007) Commercialization and use of snakes in North and Northeastern Brazil: implications for conservation and management. Biodiversity and Conservation, 16:969-985.

Alves RRN, Rosa IL (2010) Trade of animals used in Brazilian traditional medicine: trends and implications for conservation. Human Ecology 38:691-704.

Alves RRN, Vieira WLS, Santana GG (2008) Reptiles used in traditional folk medicine: conservation implications. Biodiversity and Conservation 17:2037-2049.

Alves RRN, Vieira WLS, Santana GG., Vieira KS, Montenegro PFGP (2013). Herpetofauna used in traditional folk medicine: conservation implications. Animals in traditional folk medicine. Springer, Berlin, Germany

Bauer AM (2009) Geckos in traditional medicine: forensic implications. Applied Herpetology 6:81-96.

Byard RW (2016) Traditional medicines and species extinction: another side to forensic wildlife investigation. Forensic Science, Medicine, and Pathology 12:125-127.

Chen M, Huang JH (2001) Present status of study on gecko used as traditional Chinese medicine. Shijie Kexue Jishu-Zhongyiyao Xiandaihua 3:53-56. 
Chen TH, Chang HC, Lue KY (2009) Unregulated trade in turtle shells for Chinese traditional medicine in East and Southeast Asia: the case of Taiwan. Chelonian Conservation and Biology, 8:11-18.

Chuang IC, Huang YL, Lin TH (1999) Determination of lead and cadmium in Chinese crude drugs by graphite-furnace atomic absorption spectrometry. Analytical sciences, 15:1133-1136.

Costa-Neto EM (2005) Animal-based medicines: biological prospection and the sustainable use of zootherapeutic resources. Anais da Academia Brasileira de Ciências 77:3343.

Enríque Vázquez $\mathrm{P}$, Mariaca Méndez $\mathrm{R}$, Guiascón R, Gustavo Ó, Piñera N, Jorge $E$ (2006) Uso medicinal de la fauna silvestre en los Altos de Chiapas, México. Interciencia 31:491-499.

Frazer JG, (1951) The Golden Bough. A Study in Magic and Religion. Part 6, vol. 9: The Scapegoat. Macmillan, New York,

Frembgen JW (1996) The folklore of geckos: ethnographic data from south and west Asia. Asian folklore studies 55:135-143.

Gong SP, Chow AT, Fong JJ, Shi HT (2009) The chelonian trade in the largest pet market in China: scale, scope and impact on turtle conservation. Oryx, 43:213-216.

Hazarika M, Sharma DK (2018) A Study on the Conservation Status of Mabuya Multifasciata, on the Basis of Ethnozoological Survey, in Kokrajhar District of Assam, India. International Journal of Humanities and Social Sciences 7:1-44

KSDAE (2010) Kuota Ekspor Tumbuhan Alam Dan Satwa Liar Yang Termasuk Non-Appendix CITES Untuk Periode Tahun 2010. Direktorat Jenderal Konservasi Sumber Daya Alam Dan Ekosistem, Jakarta, Indonesia

KSDAE (2016) Kuota Pengambilan Tumbuhan Alam Dan Penangkapan Satwa Liar Periode Tahun 2016. Direktorat Jenderal Konservasi Sumber Daya Alam Dan Ekosistem, Jakarta, Indonesia

KSDAE (2018) Kuota Pengambilan Tumbuhan Alam Dan Penangkapan Satwa Liar. Direktorat Jenderal Konservasi Sumber Daya Alam Dan Ekosistem, Jakarta, Indonesia
Mahawar MM, Jaroli DP (2006) Animals and their products utilized as medicines by the inhabitants surrounding the Ranthambhore National Park, India. Journal of Ethnobiology and Ethnomedicine, 2:46.

Mahendra BC (1936) Geckos and superstition. Journal of the Bombay Natural History Society. 38: 631-633.

Meiri S, Bauer AM, Allison A, Castro-Herrera, F, Chirio L, Colli G, Das I, Doan TM, Glaw F, Grismer LL, Hoogmoed M (2018) Extinct, obscure or imaginary: The lizard species with the smallest ranges. Diversity and Distributions 24:262-273.

Milner-Gulland EJ, Kholodova MV, Bekenov A, Bukreeva OM, Grachev IA, Amgalan L, Lushchekina AA (2001) Dramatic declines in saiga antelope populations. Oryx, 35:340-345.

Nazarea V, Rhoades R, Bontoyan E, Flora G (1998) Defining indicators which make sense to local people: Intra-cultural variation in perceptions of natural resources. Human Organization 57:159-170.

Ngokwey $N$ (1995) Home remedies and doctors' remedies in Feira (Brazil). Social Science \& Medicine 40:1141-1153.

Nijman V, Bergin D (2017) Reptiles traded in markets for medicinal purposes in contemporary Morocco. Contributions to Zoology 86: 39-50

Nijman V, Nekaris KAI, Bickford DP (2012) Asian medicine: small species at risk. Nature 481:265.

Nijman, V, Nekaris, KAI (2014) Trade in wildlife for medicinal and decorative purposes in Bali, Indonesia. TRAFFIC Bulletin 14: 31-36

ProFauna (2009) Wildlife trade survey on the bird markets in Java. ProFauna, Indonesia

Read BE (1934) Chinese Materia Medica. VII. Dragons and snakes. Peking Natural History Bulletin 4:297-357.

Rowley JJ, Shepherd CR, Stuart BL, Nguyen TQ, Hoang HD, Cutajar TP, Wogan GO, Phimmachak $S$ (2016) Estimating the global trade in Southeast Asian newts. Biological Conservation 199:96-100. 
Shea G, Allison A, Tallowin O, McGuire J, Iskandar D, Cai B, Wang Y, Yang J, Shang G (2018) Eutropis multifasciata. The IUCN Red List of Threatened Species 2018: e.T195295A2376842.

[http://dx.doi.org/10.2305/IUCN.UK.2018-

2.RLTS.T195295A2376842.en] Accessed on 05 December 2018.

Sheu HY (1977) Research on Chinese Animal Crude Drugs. New Medical Drug, Taipei, Taiwan.

Sofowora A (1996) Research on medicinal plants and traditional medicine in Africa. The Journal of Alternative and Complementary Medicine 2:365-372.

Thongsa-Ard IV, Thongsa-Ard P (2003) Gecko Go China. The Far Eastern Economic Review 166: 58-59.

Wagner P, Dittmann A (2014) Medicinal use of Gekko gecko (Squamata: Gekkonidae) has an impact on agamid lizards. Salamandra 50: 185186.

Whiting MJ, Williams VL, Hibbitts TJ (2013) Animals traded for traditional medicine at the Faraday market in South Africa: species diversity and conservation implications. Animals in Traditional Folk Medicine, Springer, Berlin, Germany.
Williams VL, Moshoeu TJ, Alexander GJ (2016) Reptiles sold as traditional medicine in Xipamanine and Xiquelene Markets (Maputo, Mozambique). South African Journal of Science 112:1-9.

World Health Organization (2001) Legal Status of Traditional Medicine and Complementary/Alternative Medicine: A Worldwide Review. World Health Organization, Geneva, Switzerland

You L, Wang G (2000) Chinese traditional and herbal medicines with effect to blood glucose (in Chinese). Chinese Journal Traditional Chinese Medicine 7: 32-34.

Yuwono FB (1998) The trade of live reptiles \& amphibians in Indonesia. In W. Erdelen (ed.) Conservation, Trade \& Sustainable Use of Lizards \& Snakes in Indonesia. Mertensiella 9:9-16

Zhou Z, Jiang Z (2004) International trade status and crisis for snake species in China. Conservation Biology 18:1386-1394.

Received: 11 January 2019

Accepted: 05 November 2019

Published: 19 November 2019 